\title{
Kecintaan Pada Uang dan Persepsi Anti Korupsi
}

\author{
Nizma Triana, Adi Heryadi \\ STIPSI Yogyakarta, UNJANI Yogyakarta \\ adiheryadi16@gmail.com
}

\begin{abstract}
The purpose of this study was to study the relationship between the attitude of love of money (perception of money) with the perception of anti-corruption in regional bureaucratic employees in Sleman Regency. This study uses quantitative methods that are analyzed using statistical analysis of product moment evaluations from Carl Pearson. The sample used in this study was obtained using saturated sampling technique. The sample of this research is the staff of the Sleman Regency Regional Finance and Asset Agency which gathers 77 employees. The research data was collected through a scale of love money attitude with a value $(\alpha)$ of 0.979 and an anticorruption perception scale with a value $(\alpha)$ of 0.960. Statistical test results obtained with a positive correlation coefficient of 0.514, with a significance level of 0.000 ( $p<0.05)$, this shows a significant positive relationship between the attitude of love of money with the perception of anti-corruption. Successful, the higher the attitude of love for money, the higher the perception of anti-corruption needed by employees and vice versa, the lower the attitude of love of money, the lower the perception of anti-corruption that demands employees. The average subject has an attitude of love for money and perceptions of anti-corruption in the medium category. The effective contribution of the love attitude of money to the perception of anti-corruption amounted to $26.4 \%$ and $73.6 \%$ of the perception of anti-corruption by other factors in the study.
\end{abstract}

Keywords: love of money attitude, anti-corruption perception, regional bureaucracy.

\begin{abstract}
Abstrak
Tujuan penelitian ini adalah untuk mengetahui hubungan antara sikap love of money (kecintaan pada uang) dengan persepsi anti korupsi pada pegawai birokrasi daerah di Kabupaten Sleman. Penelitian ini menggunakan metode kuantitatif yang dianalisa menggunakan analisis statistik korelasi product moment dari Carl Pearson. Sampel yang digunakan dalam penelitian ini diperoleh menggunakan teknik sampling jenuh. Sampel penelitian ini adalah pegawai Badan Keuangan dan Aset Daerah Kabupaten Sleman yang berjumlah 77 pegawai. Data penelitian dikumpukan melalui skala sikap love of money dengan nilai $(\alpha)$ sebesar 0,979 dan skala persepsi anti korupsi dengan nilai $(\alpha)$ sebesar 0,960. Hasil uji statistik diperoleh koefisien korelasi $\left(\mathrm{r}_{\mathrm{xy}}\right)$ positif sebesar 0,514, dengan taraf signifikansi sebesar $0,000(\mathrm{p}<0,05)$, hal ini menunjukkan bahwa ada hubungan positif yang signifikan antara sikap love of money dengan persepsi anti korupsi. Artinya, semakin tinggi sikap love of money maka semakin tinggi persepsi anti korupsi yang dimiliki pegawai dan sebaliknya, semakin rendah sikap love of money maka semakin rendah persepsi anti korupsi yang dimiliki pegawai. Rata-rata subjek memiliki sikap love of money dan persepsi anti korupsi berada dalam kategori sedang. Sumbangan efektif sikap love of money terhadap persepsi anti korupsi sebesar 26,4\% dan 73,6\% persepsi anti korupsi dipengaruhi oleh faktor-faktor lain diluar penelitian.
\end{abstract}

Kata kunci : sikap love of money, persepsi anti korupsi, birokrasi daerah.

\section{Pendahuluan}

Korupsi adalah masalah umum di seluruh dunia yang telah ada di berbagai budaya selama berabad-abad. Korupsi telah terjadi di berbagai negara di dunia, sehingga mendorong masyarakat internasional untuk bekerjasama dalam pemberantasan korupsi. Saat ini, tingkat masalah di seluruh dunia begitu besar sehingga Majelis Umum Perserikatan Bangsa-Bangsa (PBB) pada tahun 2003 memutuskan untuk menunjuk 9 Desember sebagai "Hari Anti Korupsi Internasional" agar meningkatkan kesadaran akan korupsi dan membantu mengurangi kejadiannya. Menurut Bakonis, dkk., (2006) korupsi adalah membeli atau menjual keputusan yang melanggar keadilan. Keadilan dalam bentuk hukum (bila aturan tertulis dilanggar) maupun moral (bila tidak ada standar perilaku yang ditetapkan namun akal sehat menunjukkan ketidakadilan suatu 
tindakan). Dalam kasus Indonesia, banyak ahli dan pengamat menyatakan bahwa dibandingkan dengan kasus korupsi di negara lain, fenomena korupsi yang terjadi di Indonesia telah menjadi penyakit kronis dan sulit untuk pulih (Isra, 2009). Sementara menurut Siahaan (2009) birokrasi daerah terdiri dari pemerintah daerah (Gubernur \& Walikota / Bupati) dan perangkat daerah sebagai unsur penyelenggara pemerintahan daerah. Undang-Undang Nomor 32 Tahun 2004 Tentang Pemerintahan Daerah menegaskan bahwa titik berat penyelenggaraan penyerahan wewenang pemerintahan oleh pemerintah pusat diletakkan pada pemerintahan kabupaten dan kota untuk mengatur dan mengurus urusan pemerintahan dalam sistem Negara Kesatuan Republik Indonesia. Penelitian Desiana (2014) menunjukkan bahwa penyelenggaraan pemerintahan daerah secara umum belum mencapai hasil yang sangat memuaskan karena anggaran yang diterima oleh sebuah birokrasi lebih ditentukan oleh kebutuhan bukan hasil yang akan diberikan birokrasi pada masyarakatnya. Selain itu, struktur, norma, nilai dan regulasi yang ada masih berorientasi pada pemenuhan kepentingan penguasa daripada pemenuhan hak sipil warga negara sehingga hasil dan kinerja cenderung rendah dalam kehidupan birokrasi (Savitri, 2014). Desiana (2014) menambahkan bahwa dalam kultur yang demikian, korupsi, kolusi dan nepotisme menjadi hal yang umum, sehingga kualitas pelayanan dan pemerintahan seringkali terabaikan. Hasil pra-survey yang dilakukan oleh Hartiningsih (2017) di kantor Badan Keuangan dan Aset Daerah (BKAD) Kabupaten Sleman menunjukkan bahwa nilai rata-rata kinerja karyawan belum sesuai dengan standar yang telah ditetapkan BKAD Kabupaten Sleman, tingginya jumlah karyawan yang terlambat atau datang ke kantor tidak sesuai dengan jam masuk kantor yang telah ditetapkan, dan banyak karyawan yang belum efektif dalam penggunaan jam kerja. Hal tersebut menunjukkan adanya penyelewengan atau pelanggaran terhadap nilai-nilai anti korupsi yang meliputi kurangnya tanggungjawab, kerja keras dan disiplin atau perilaku yang diharapkan dari seorang pegawai birokrasi daerah. Menurut Astuti (2013), penyelewengan terhadap standar- standar etis mengenai perilaku yang diharapkan dari seorang pegawai menyebabkan terjadinya korupsi. Menurut Abidin dan Siswadi (2015) terjadinya korupsi disebabkan oleh faktor internal atau psikologis, salah satu faktor tersebut adalah persepsi. Persepsi adalah proses memberikan makna pada stimuli inderawi (Supratman dan Mahadian, 2016). Penelitian Abidin, dkk., (2011) menemukan bahwa persepsi tentang korupsi, persepsi tentang penegakkan hukum, persepsi tentang norma sosial, dan persepsi tentang pemimpin dapat mempengaruhi perilaku korupsi (Abidin dan Siswadi, 2015). Kemudian, Heryadi, dkk., (2019) dalam penelitiannya menguji efektivitas pelatihan anti korupsi untuk meningkatkan persepsi anti korupsi pada siswa SD. Persepsi anti korupsi merupakan suatu cara pandang terhadap nilai-nilai anti korupsi yang tidak menyetujui terhadap berbagai upaya yang dilakukan oleh setiap orang untuk melakukan tindakan korupsi sehingga dapat mendorong pelaksanaan pembangunan nasional. Menurut Puspito, dkk., (2011), nilai-nilai anti korupsi tersebut perlu diterapkan oleh setiap individu untuk dapat mengatasi penyebab terjadinya korupsi. Wahyudi \& Sopanah (2010) menyebutkan sebab-sebab manusia terdorong untuk melakukan korupsi antara lain, yaitu karena sifat tamak, moral yang kurang kuat, gaya hidup konsumtif dan tidak mau bekerja keras. Pope (2008) menyatakan bahwa saat ini, korupsi dilakukan oleh orang kaya dan berpendidikan tinggi. Maka dari itu, peneliti berasumsi bahwa terdapat penyebab lainnya yang mendorong seseorang melakukan korupsi selain kurangnya pendapatan atau gaji para pelaku korupsi, yaitu kecintaan terhadap uang. Penelitian Tang \& Liu (2011) menunjukkan bahwa orang dengan kecintaan terhadap uang yang tinggi dan persepsi terhadap karakter pribadi supervisor yang rendah memiliki perilaku yang tidak etis. Perilaku tidak etis tersebut terdiri dari beberapa sub-konstruksi yaitu penyalahgunaan sumber daya, pencurian, penipuan dan korupsi (Tang, Chen \& Sutarso, 2008). Kemudian Chen, Tang \& Tang (2014) dalam penelitiannya menemukan bahwa kecintaan terhadap uang dapat memprediksi kecurangan. Dari uraian di atas dan melihat fenomena yang terjadi peneliti tertarik untuk mengetahui bagaimana hubungan antara kecintaan pada uang dengan persepsi anti korupsi pada pegawai 
birokrasi daerah di Kabupaten Sleman. serta .megetahui kategori kecintaan pada uang dengan persepsi anti korupsi pada pegawai birokrasi daerah. Penelitian ini diharapkan semakin memperkaya khasanah penelitian psikologi yang berkaitan dengan persepsi anti korupsi.

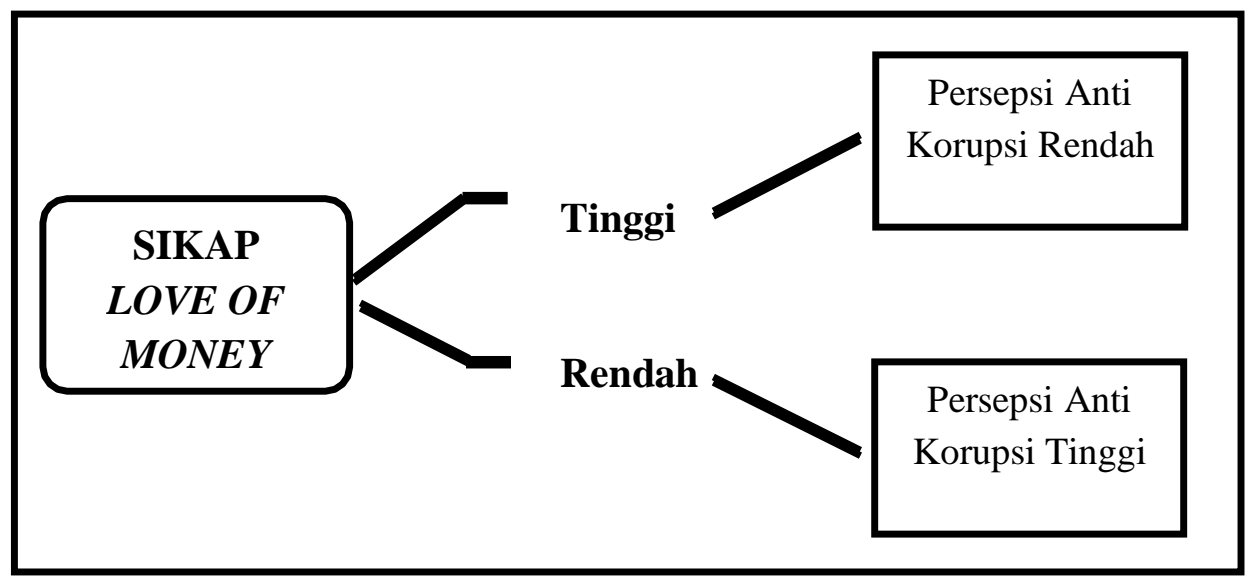

Gambar 1. Ilustrasi Hubungan Antara Sikap Love of Money dengan Persepsi Anti Korupsi

\section{Metode Penelitian}

2.1 Identifikasi Variabel Penelitian

Variabel yang digunakan pada penelitian ini mencakup dua variabel yaitu, variabel dependent dan variabel independent. Adapun variabel-variabel tersebut adalah :

Variabel Dependent : Persepsi Anti Korupsi

Variabel Independent : Sikap Love of Money.

\subsection{Definisi Operasional Variabel Penelitian}

Persepsi Anti Korupsi

Persepsi anti korupsi adalah cara pandang individu atau pemrosesan lebih lanjut dari nilai-nilai anti korupsi yang didapatkan melalui pengalaman sehingga kita dapat menyadari sesuatu yang benar, baik dan membangun untuk tidak mendukung upaya yang merugikan negara. Persepsi anti korupsi diungkap dengan skala yang disusun peneliti berdasarkan pandangan individu terhadap nilai-nilai anti korupsi yang dikemukakan oleh Puspito, dkk., (2011), yaitu kejujuran, kepedulian, kemandirian, kedisiplinan, tanggungjawab, kerja keras, sederhana, keberanian dan keadilan.

Skala Sikap Persepsi Anti Korupsi dengan nilai $(\alpha)$ sebesar 0,960

Tabel 1.

Skala Persepsi Anti Korupsi

\begin{tabular}{lllll}
\hline \multirow{2}{*}{ Nilai } & \multicolumn{2}{l}{ Nomor Aitem } & Jumlah \\
\cline { 3 - 4 } & & Favorable & Unfavorable & \\
\hline 1 & Kejujuran & 19,46 & 28,37 & 5 \\
2 & Kepedulian & $2,20,38$ & 11,29 & 4 \\
3 & Kemandirian & 12,30 & 4,39 & 6 \\
4 & Kedisiplinan & $3,22,40$ & $13,31,49$ & 5 \\
5 & Tanggung Jawab & 23,51 & $5,14,32$ & 4 \\
6 & Kerja Keras & 24,42 & 15,50 & 4 \\
7 & Sederhana & 7,43 & 25,34 & 5 \\
8 & Keberanian & $8,26,44$ & 35,52 & 5 \\
9 & Keadilan & 36,53 & $9,27,45$ & $\mathbf{4 2}$ \\
\hline Jumlah & $\mathbf{2 1}$ & $\mathbf{2 1}$ & 5 \\
\hline
\end{tabular}




\section{Sikap Love of Money}

Sikap love of money adalah pendapat, keyakinan, evaluasi dan perasaan emosional yang menjadi dasar perilaku seseorang terhadap uang sebagai motivator, simbol kesuksesan, kepentingan dan kekayaan yang bukan merupakan kebutuhannya. Sikap love of money diukur dengan menggunakan Skala Sikap Love of Money yang disusun sendiri oleh peneliti berdasarkan komponen-komponen sikap love of money menurut Tang (2016) yang terdiri dari komponen afektif (meliputi kaya, motivator, dan kepentingan), komponen perilaku (meliputi menghasilkan uang, menganggarkan uang, menyumbangkan uang, dan berkonstribusi), dan komponen kognitif ( meliputi rasa hormat, pestasi dan kekuatan). Skala Love of Money dengan $(\alpha)$ sebesar 0,979.

Tabel 2.

Skala Sikap Love of Money

\begin{tabular}{lllll}
\hline \multirow{2}{*}{ Aspek } & Indikator & Nomor Aitem & Unfavorabel & Jumlah \\
\cline { 3 - 3 } & Kaya & Favorabel & 7,39 & 4 \\
\multirow{2}{*}{ Afektif } & Motivator & 1,21 & 8,32 & 4 \\
& Kepentingan & 2,22 & 11,33 & 4 \\
& Menghasilkan uang & 28,34 & 16,27 & 4 \\
\multirow{3}{*}{ Perilaku } & Mengatur uang & 35,23 & 12,25 & 4 \\
& Menyumbangkan uang & $3,9,36$ & 17 & 4 \\
& Berkonstribusi & 10,13 & 6,18 & 4 \\
\multirow{2}{*}{ Kognitif } & Rasa menghormati & 14,37 & 26,40 & 4 \\
& Prestasi & $5,24,29$ & 19,41 & 5 \\
& Kekuatan & 15,30 & 4,38 & 4 \\
\hline
\end{tabular}

\section{Populasi Dan Sampel Penelitian}

Populasi adalah wilayah generalisasi yang terdiri atas obyek/subyek yang mempunyai kualitas dan karakteristik tertentu yang ditetapkan oleh peneliti untuk dipelajari kemudian ditarik kesimpulannya (Sugiono, 2017). Populasi dalam penelitian ini adalah seluruh pegawai Badan Keuangan dan Aset Daerah (BKAD) Kabupaten Sleman yang berjumlah 101 pegawai.

Sampel adalah bagian dari jumlah dan karakteristik yang dimiliki oleh populasi (Sugiono, 2017). Sampel harus memiliki paling sedikit sifat yang sama dengan populasi karena hasil dari sampel akan digeneralisasikan pada suatu populasi (Wade dan Tavris, 2008). Sampel dalam penelitian ini dipilih dengan tekhnik sampling jenuh dengan jumlah sampel sebanayak 77 pegawai Badan Keuangan dan Aset Daerah (BKAD) Kabupaten Sleman.

\section{Teknik Analisis Data}

Teknik analisis data dalam penelitian ini menggunakan statistik. Hipotesis dalam penelitian ini diuji dengan teknik korelasi, yaitu Pearson Product Moment. Analisis dilakukan dengan menggunakan bantuan SPSS for windows versi 24.00. Dalam penelitian ini persyaratannya adalah koefisien korelasi bergerak dari 0 hingga -1 . Bila koefisien korelasi bergerak dari 0 sampai +1 maka dinyatakan berkorelasi positif, dan apabila korelasi bergerak dari 0 sampai -1 maka dinyatakan berkorelasi negatif (Pratisto, 2005)

\section{Hasil Dan Pembahasan}

\subsection{Hasil Uji Asumsi}

Uji Normalitas

Uji normalitas bertujuan untuk menguji apakah dalam model regresi, variabel pengganggu atau residual mempunyai distribusi normal. Uji normalitas digunakan untuk mengetahui apakah data yang digunakan berdistribusi normal atau tidak. Uji normalitas data dalam penelitian ini menggunakan uji Kolmogrov-Smirnov $(K-S)$ one sample. Dasar pengambilan keputusan dalam penelitian ini adalah bila nilai Asymp.Sig (2-tailed) lebih besar dari 0,05 (p>0,05) maka dapat disimpulkan bahwa data tersebut berdistribusi normal.

Berdasarkan pengolahan data yang dilakukan peneliti dengan menggunakan SPSS Versi 24 Windows, maka hasil uji normalitas data penelitian ini sebagai berikut : 
Tabel 3.

Uji Normalitas

\begin{tabular}{lllll}
\hline \multicolumn{2}{l}{ One-Sample Kolmogorov-Smirnov Test } & & \\
\hline & & Love of Money & Persepsi & Korupsi \\
\hline N & Mean & 77 & 77 \\
Normal Parameters & a,b & 109,16 & 123,35 \\
& Std. Deviation & 8,502 & 9,854 \\
Most Extreme Differences & Absolute &, 068 &, 086 \\
& Positive &, 068 &, 060 \\
& Negative &,- 053 &,- 086 \\
Test Statistic & &, 068 &, 2086 \\
Asymp. Sig. (2-tailed) &, $200^{\text {c,d }}$ & \\
\hline a. Test distribution is Normal. & & \\
b. Calculated from data. & & \\
c. Lilliefors Significance Correction. & & \\
d. This is a lower bound of the true significance. & &
\end{tabular}

Dari tabel diatas dapat dilihat bahwa uji normalitas menyatakan nilai Asymp. Sig. (2-tailed) pada variabel sikap love of money dan persepsi anti korupsi sebesar $0,2(\mathrm{p}>0.05)$ sehingga sebaran skor sikap love of money dan persepsi anti korupsi berada dalam sebaran yang normal.

Uji Linearitas

Uji linearitas dilakukan untuk mengetahui apakah dua variabel mempunyia hubungan yang linear atau tidak linear secara signifikan. Dasar pengambilan keputusan dalam penelitian ini adalah bila nilai Deviation from Linearity lebih besar dari 0,05 ( $>0,05)$ maka dapat disimpulkan bahwa kedua variabel berkorelasi linear.

Berdasarkan pengolahan data yang dilakukan peneliti dengan menggunakan SPSS Versi 24 Windows, maka hasil uji linearitas data penelitian ini sebagai berikut :

Tabel 4.

Uji Linearitas

\begin{tabular}{|c|c|c|c|c|c|c|c|}
\hline \multicolumn{8}{|l|}{ ANOVA Table } \\
\hline & & & \multicolumn{5}{|l|}{ Sum of } \\
\hline Persepsi Anti & Between & (Combined) & 4508,616 & 33 & 136,625 & 2,046 &, 014 \\
\hline Korupsi * Love of & Groups & Linearity & 1949,566 & 1 & 1949,566 & 29,200 & ,000 \\
\hline \multirow[t]{3}{*}{ Money } & & $\begin{array}{l}\text { Deviation from } \\
\text { Linearity }\end{array}$ & 2559,050 & 32 & 79,970 & 1,198 & ,287 \\
\hline & Within G & & 2870,917 & 43 & 66,766 & & \\
\hline & Total & & 7379,532 & 76 & & & \\
\hline
\end{tabular}

Dari Tabel diatas dapat dilihat bahwa uji linearitas menunjukkan bahwa Deviation from Linearity yaitu 1,198 lebih besar dari 0,05 atau $1.198>0.05$ sehingga hubungan kedua variabel yaitu sikap love of money dengan persepsi anti korupsi adalah linear dengan nilai kofisien F sebesar 1,198 dan signifikansinya sebesar 0,287 .

Uji Hipotesis

Hipotesis dalam penelitian ini diuji dengan teknik korelasi, yaitu Pearson Product Moment. Analisis dilakukan dengan menggunakan bantuan SPSS for windows versi 24.00. Dalam penelitian ini persyaratannya adalah koefisien korelasi bergerak dari 0 hingga -1 . Bila koefisien korelasi bergerak dari 0 sampai +1 maka dinyatakan berkorelasi positif, dan apabila korelasi bergerak dari 0 sampai -1 maka dinyatakan berkorelasi negatif (Pratisto, 2005).

Berdasarkan pengolahan data yang telah dilakukan oleh peneliti, hasil uji hipotesis dapat dilihat pada tabel berikut ini : 
Tabel 5.

Uji Hipotesis

\begin{tabular}{lllll}
\hline Correlations & & & & \\
\hline & & Love of Money & $\begin{array}{l}\text { Persepsi } \\
\text { Korupsi }\end{array}$ & Anti \\
\hline Love of Money & Pearson Correlation & 1 &, $514^{* *}$ \\
& Sig. (2-tailed) & 77 &, 000 \\
\multirow{2}{*}{ Persepsi Anti Korupsi } & N & Pearson Correlation &, $514^{* *}$ & 1 \\
& Sig. (2-tailed) &, 000 & \\
& $\mathrm{~N}$ & 77 & 77 & \\
& **. Correlation is significant at the 0.01 level (2-tailed). & &
\end{tabular}

Hasil uji hipotesis diatas menunjukkan koefisien korelasi (pearson correlation) sebesar 0,514 dan taraf signifikansi sebesar 0,000. Koefisien korelasi tersebut lebih besar dari $0.5(\mathrm{p}<0.5)$ dan taraf signifikansi (2-tailed) lebih kecil dari $0.05(\mathrm{p}<0.05)$ sehingga dapat dikatakan bahwa korelasi antara sikap love of money dengan persepsi anti korupsi cukup kuat.

Tanda positif pada koefisien korelasi menunjukkan bahwa arah hubungan kedua variabel tersebut adalah positif. Artinya, semakin tinggi sikap love of money maka semakin tinggi pula persepsi anti korupsi pada pegawai BKAD Kabupaten Sleman. Sebaliknya, semakin rendah sikap love of money maka semakin rendah pula persepsi anti korupsi yang dimiliki pegawai BKAD Kabupaten Sleman. Dari penelitian ini juga diperoleh kategorisasi sikap love of money subyek penelitian maupun persepsi anti korupsi nya seperti pada gambar berikut :

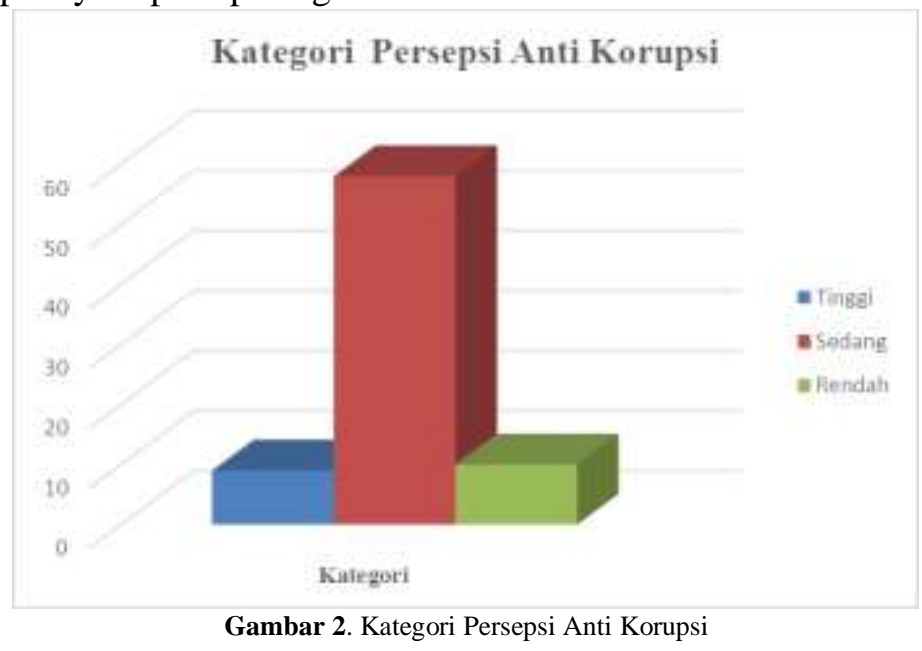

Tabel dan diagram diatas menunjukkan bahwa pegawai BKAD Kabupaten Sleman memiliki persepsi anti korupsi yang dihitung dari 77 sampel, pegawai yang memiliki kategori rendah sebanyak 10 pegawai (13\%), pegawai yang memiliki kategori sedang sebanyak 58 pegawai $(75 \%)$ dan pegawai yang memiliki kategori tinggi berjumlah 9 pegawai (12\%). Jadi, dapat disimpulkan bahwa kecenderungan persepsi anti korupsi pegawai BKAD Kabupaten Sleman berada pada kategori sedang yaitu sebanyak 58 pegawai $(75 \%)$ dari jumlah sampel yang berjumlah 77 pegawai.

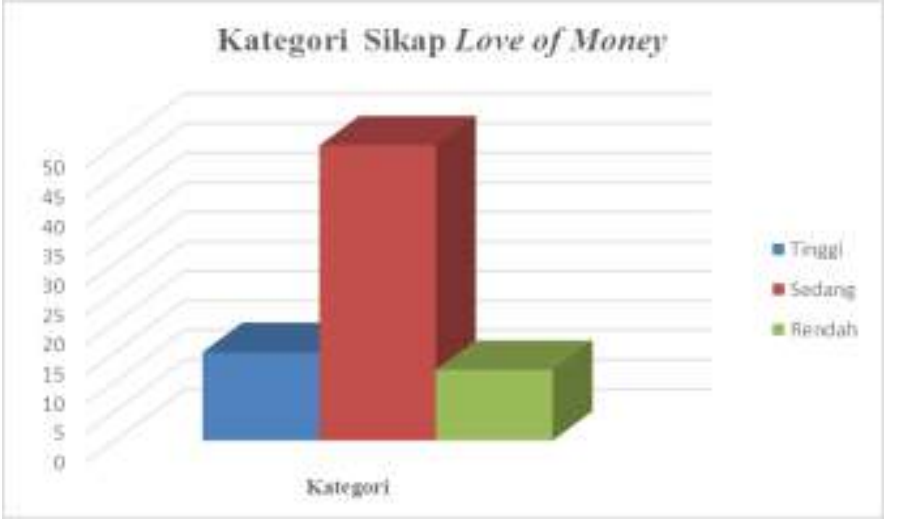

Gambar 3. Kategori Sikap Love of Money

Psyche 165 Journal Terakredetasi Sinta 5 
Tabel dan diagram diatas menunjukkan bahwa pegawai BKAD Kabupaten Sleman memiliki sikap love of money yang dihitung dari 77 sampel, pegawai yang memiliki kategori tinggi sebanyak 15 pegawai $(19 \%)$, pegawai yang memiliki kategori sedang sebanyak 50 pegawai $(65 \%)$ dan pegawai yang memiliki kategori rendah sebanyak 12 pegawai (16\%). Jadi, dapat disimpulkan bahwa kecenderungan sikap love of money pegawai BKAD Kabupaten Sleman berada pada kategori sedang yaitu sebanyak 50 pegawai (65\%) dari jumlah sampel yang berjumlah 77 pegawai.

Berdasarkan dari berbagai tahap analisis statistik diatas. menunjukkan bahwa terdapat hubungan positif antara sikap love of money dengan persepsi anti korupsi pada pegawai birokrasi daerah Kabupaten Sleman. Tidak ada penelitian sebelumnya yang sejalan dengan hasil penelitian ini. Mengingat keaslian penelitian ini yang belum pernah ada penelitian yang menguji secara langsung ada atau tidaknya hubungan antara sikap love of money dengan persepsi anti korupsi. Namun, adanya hubungan yang signifikan antara sikap love of money dengan persepsi anti korupsi sejalan dengan penelitian Elias (2010) yang menyatakan bahwa love of money dengan persepsi etis memiliki hubungan yang signifikan. Senada dengan penelitian yang dilakukan oleh Pradanti dan Prastiwi (2014) menunjukkan bahwa love of money berpengaruh terhadap persepsi etis. Hasil penelitian tersebut didukung oleh Tang dan Chiu (2003) yang berkesimpulan bahwa kecintaan uang seseorang memiliki dampak yang signifikan terhadap perilaku tidak etis. Tang (2016) menambahkan bahwa uang sangat penting sehingga dapat mempengaruhi perilaku atau sikap seseorang. Hasil penelitian ini menunjukkan adanya hubungan yang positif antara sikap love of money dengan persepsi anti korupsi. Hasil tersebut tidak sejalan dengan penelitian-penelitian sebelumnya meskipun tidak secara langsung meneliti hubungan antara sikap love of money dengan persepsi anti korupsi. Azis (2015) dalam penelitiannya menemukan bahwa love of money berpengaruh negatif dan signifikan terhadap persepsi etis mahasiswa. Persepsi etis mahasiswa adalah bagaimana mahasiswa bersikap menilai satu keadaan atau perilaku pelanggaran. Berbeda dengan persepsi etis, persepsi anti korupsi adalah pandangan seseorang terhadap nilai-nilai untuk tidak melakukan tindakan korupsi. Begitu pula penelitian Basri (2015) yang menunjukkan bahwa semakin besar tingkat love of money mahasiswa maka etika penggelapan pajak juga semakin tinggi. Penelitian Nkundabanyanga, dkk., (2011) menunjukkan bahwa jika seseorang bersedia melakukan tugas yang tidak profesional untuk keuntungan sendiri atau jika mereka memiliki hasrat yang membara untuk sukses terlepas bagaimana mereka harus berhasil, ini pasti akan berakibat pada perilaku yang tidak etis. Tang dan Chiu (2003) menemukan bahwa love of money berkorelasi dengan perilaku tidak etis. Perilaku tidak etis tersebut antara lain, yaitu penyalahgunaan sumber daya, pencurian, penipuan dan korupsi (Tang, Chen dan Sutarso, 2008). Penyalahgunaan sumber daya, pencurian, penipuan dan korupsi merupakan tindakan atau perilaku yang bertentangan dengan nilai-nilai anti korupsi. Menurut Singhapakdi, dkk., (2013) love of money merupakan pemicu berbagai krisis etika karena uang merupakan alat utama untuk memotivasi pegawai, uang merupakan ukuran yang paling mudah untuk menilai kinerja perusahaan, dan uang merupakan ukuran kesejahteraan bagi sebagian besar pegawai. Sedangkan menurut Tang, Chen, dan Sutarso (2008), uang dapat memberikan efek positif yaitu memotivasi seseorang untuk meningkatkan kinerja, namun juga memiliki efek negatif untuk melakukan kecurangan sehingga memperoleh tambahan bonus berupa uang. Sesuai dengan hasil riset sebelumnya bahwa love of money seseorang memiliki dampak yang signifikan terhadap perilaku tidak etis (Tang dan Chiu, 2003) karena uang sangat penting sehingga dapat mempengaruhi perilaku atau sikap seseorang (Tang, 2016). Selain itu, uang merupakan ukuran kesejahteraan seseorang (Singhapakdi dkk, 2013) namun pegawai masih dapat menjaga etika atau peraturan / norma yang dapat digunakan sebagai acuan bagi perilaku seseorang yang berkaitan dengan tindakan yang baik atau buruk yang dilakukan seseorang dan merupakan kewajiban dari tanggung jawab moral. Hal tersebut sesuai dengan penelitian Rindayanti dan Budiarto (2017) tentang hubungan antara love of money dengan persepsi etis pada mahasiswa akutansi bahwa meskipun tujuan kuliah untuk mencapai kesuksesan dan memiliki banyak uang, namun mahasiswa masih dapat menjaga etika. 
Dari hasil-hasil penelitian-penelitian sebelumnya itulah peneliti menyusun kerangka pemikiran seperti pada gambar 1 dan hipotesis penelitian. Sedangkan pada komponen-komponen yang digunakan oleh peneliti telah mengalami penambahan komponen, yaitu komponen perilaku yang meliputi menghasilkan uang, menganggarkan uang, menyumbangkan uang, dan berkonstribusi. Empat indikator komponen perilaku tersebut merupakan perilaku-perilaku yang menerapkan nilainilai anti korupsi.

Pertama, menghasilkan uang. Seseorang yang memiliki sikap love of money tentunya akan berusaha untuk menghasilkan uang. Menghasilkan uang tidak hanya dilakukan dengan satu cara, namun bisa ditempuh dengan berbagai cara dan usaha. Usaha yang dilakukan untuk menghasilkan uang memerlukan kerja keras. Kerja keras merupakan salah satu nilai anti korupsi (Puspito dkk, 2011) yang menjadi indikator dalam penyusunan skala persepsi anti korupsi.

Kedua, menganggarkan uang. Seseorang yang memiliki sikap love of money memiliki kemampuan untuk menganggarkan uang yang dimilikinya. Uang tersebut perlu dianggarkan dengan baik agar dapat memenuhi kebutuhannya. Individu yang mapu menganggarkan uang yang dimilikinya dengan baik tentunya memiliki kemandirian, kesederhanaan dan keadilan. Kemandirian, kesederhanaan dan keadilan merupakan nilai-nilai anti korupsi yang juga digunakan peneliti untuk menyusun skala persepsi anti korupsi.

Ketiga, menyumbangkan uang. Seseorang yang memiliki sikap love of money juga menyumbangkan uangnya kepada orang lain yang membutuhkannya. Dalam jurnalnya, Chiu, Tang, dan Tang (2014) memberikan contoh indikator menyumbangkan uang ini dengan memberikan sumbangan kepada organisasi amal atau gereja. Menyumbangkan uang merupakan penerapan nilainilai anti korupsi, yaitu kepedulian dan keadilan.

Keempat, berkontribusi. Berkonsribusi yang dimaksud adalah ketika seseorang memberikan kontribusi yang lebih maka ia akan mendapatkan uang yang lebih banyak. Orang yang memiliki love of money cenderung berusaha untuk berkontribusi dalam pekerjaannya. Sesuai dengan Tang dkk, 2008) berpendapat bahwa uang dapat memberikan dan memotivasi seseorang untuk meningkatkan kinerja seseorang. Sehingga seseorang dengan love of money perlu menerapkan kedisiplinan, keberanian, kerja keras, tanggung jawab, dan kemandirian dalam pekerjaannya sehingga dapat berkontribusi dengan baik.

\section{Penutup}

Peneliti menyadari bahwa penelitian psikologi tentang love of money dan persepsi anti korupsi masih sangat terbatas seperti masih terbatas nya yang dilakukan oleh peneliti dalam penelitian ini, namun semangat untuk terus mengembangkan dan meneliti lebih jauh merupakan semangat yang ingin di lakukan peneliti untuk Indonesia emas tahun 2045 yang bebas korupsi.

\section{Daftar Pustaka}

[1] Abidin, Z., \& Siswadi, A. G. P. (2015). Psikologi Korupsi. Bandung: Remaja Rosdakarya.

[2] Astuti, P. (2013). Politik korupsi: kendala sistemik pemberantasan korupsi di Indonesia. E-journal Universitas Diponegoro. Diunduh dari https://ejournal.undip.ac.id/index.php/politika/article/download/4917/4455

[3] Aziz, I. T. (2015). Pengaruh love of money dan machiavellian terhadap persepsi etis mahasiswa akuntansi (studi empiris pada mahasiswa akuntansi angkatan 2013 dan angkatan 2014). Jurnal Nominal. 4 (2), 31-44. Doi: 10.24843.EJA.2017.v21.i03.p20.

[4] Bakonis, E., Nielsen, A., Valcekausklene, V., Martinkeniene, A., \& Paukstiene, R. (2006). Anti-corruption Studies in General Education Schools. Lithuania: Modern Didactics Centre

[5] Basri, M. Y. (2015). Pengaruh gender, religiusitas dan sikap love of money pada persepsi etika penggelapan pajak mahasiswa akuntansi. Jurnal Ilmiah Akuntansi dan Bisnis. 10 (1), 45-54. Doi: 10.24843/JIAB.2015.v10.i01

[6] Chen, J., Tang, L., \& Tang, N. (2014). Temptation, monetary intelligence (love of money), and enviromental context on unethiccal intentions and cheating. J Bus Ethics. 123 (2), 197-219. Doi: 10.1007/s10551-013-1783-2

[7] Desiana, A. (2014). Reformasi Birokrasi Pemerintahan Daerah Menuju Good Governance. JMP. 1 (1), 19-48. Diunduh dari_ https://online-journal.unja.ac.id/index.php/jmp/article/view/2092

[8] Elias, R. Z. (2010). The Relationship Between Accounting Student Love of Money and Their Ethical Perception. Managerial Auditing Journal. 25 (3). Doi: 10.1108/02686901011026369 
[9] Hartiningsih, M. 2017. Pengaruh Disiplin dan Motivasi Kerja Terhadap Kinerja Karyawan (studi kasus pada Badan Keuangan dan Aset Daerah Kabupaten Sleman). Skripsi Universitas Negeri Yogyakarta. Diunduh dari http://eprints.uny.ac.id/53291/1/MariaHartiningsih_\%2013808141002.pdf

[10] Heryadi, A., Sari, R. E.,\& Winahyu, G. S. (2019). Developing anti-corruption perceptions of elementary school students throuugh anti-corruption training. ASEAN Comparative Education Research Network Conference. 14-20. ISBN: 978-983-226-959. Doi: $10.31227 /$ osf.io/26c3n

[11] Isra, S. (2009). Catatan Hukum Saldi Isra: Kekuasaan dan Perilaku Korupsi. Jakarta: PT Kompas MediaNusantara.

[12] Nkundabanyanga, A. K., Mpamizo, B., Omagor, C., \& Ntayi, J. M. (2011). The love of money, pressure to petform and unethical marketing behavior in the cosmetic industry in uganda. International Journal of Marketing Studies. 3 (4), 40-49. Doi: 10.5539/ijms.v3n4p40.

[13] Pope, J. (2008). Strategi Memberantas Korupsi (Edisi Ringkas). Jakarta: Transparency International Indonesia

[14] Pradanti, N. R., \& Prastiwi, A. (2014). Analisis pengaruh love of money terhadap persepsi etis mahasiswa akuntansi. Diponegoro Journal Accounting. 3 (3), 1-12. ISSN: 2337-3792

[15] Pratisto, A. (2005). Cara Mudah Megatasi Masalah Statistik dan Rancangan Percobaan dengan SPSS. 12. Jakarta: Elex Media Komputindo.

[16] Puspito dkk. (2011). Pendidikan Anti-Korupsi Untuk Perguruan Tinggi. Jakarta: Kementrian Pendidikan dan Kebudayaan RI

[17] Rindayanti., \& Budiarto, D. S. (2017). Hubungan antara love of money, machiavellian dengan persepsi etis: analisis berdasarkan perspektif gender. Akuntabilitas: Jurnal Ilmu Akuntansi. 10 (2), 261-272. Doi: 10.15408/akt.vI012.6137

[18] Savitri, Y. (2014). Hubungan Kapasitas Aparatur dengan Pewujudan Good Governance. Jejaring Administrasi Publik. 1 (1), 470479. Diunduh dari http://journal.unair.ac.id/download-fullpapers-admpcc9279d8c3full.pdf

[19] Siahaan, H. (2009). Manajemen Risiko Pada Perusahaan dan Birokrasi. Jakarta: Elex Media Komputido.

[20] Singhapakdi, A., Vitell, S., Lee, D., \& Nisius, A., Yu, G. (2012). The influence of love of money and religiosity on ethical decision making in marketing. Journal of Business Ethics. 114, 183-191

[21] Sugiono. (2017). Metode Penelitian Kuantitatif, Kualitatif, dan R\&D. Bandung: Alfabeta.

[22] Supratman, L. P., \& Mahadian, A. B. (2016). Psikologi Komunikasi. Yogyakarta: Deepublish

[23] Tang, L., Chen, Y., \& Sutarso, T. (2008). The love of money, machiavellianism, risk tolerance, and unethical behavior. Bad Apples in Bad (Business) Barrels. 46 (2), 243-264. Doi: 10.1108/00251740810854140

[24] Tang, L., \& Chiu, R. K. (2003). Income, money ethic, pay satisfaction, commitment, and unethical bbehavior: is the love of money the root of evil for hong kong employees?. Journal of Business Ethics. 46 (1), 13-30. Doi: 10.1023/A:1024731611490

[25] Tang, L., \& Liu, H. (2013). Love of money and unethical behavior intention: does an authentic supervisor's personal integrity and character (aspire) make a difference?. J Bus Ethics. 107 (3), 295-312. Doi: 10.1007/s10551-012-1407-2

[26] Tang, L. (2016). Theory of monetary intelligence: money attitudes-religious values, making money, making ethical decisions and making the grade. Journal of Business Ethics. 133, 583-603. Doi: 10.1007/s10551-014-2411-5

[27] Undang-Undang Nomor 32 Tahun 2004 Tentang Pemerintahan Daerah, Lembaran Negara Republik Indonesia Tahun 2004 Nomor 125. Jakarta

[28] Wade, C., \& Tavris, C. (2008). Psikologi Edisi Kesembilan Jilid 1. Jakarta: Erlangga

[29] Wahyudi, I., Sopanah. (2010). Pengaruh akuntabilitas publik, partisipasi masyarakat dan transparansi kebijakan publik terhadap hubungan antara pengetahuan anggaran dengan pengawasan keuangan daerah (APBD). Ejournal UMM. Diunduh dari ejournal.umm.ac.id/index.php/legality/article/view/308/321 